\title{
Impasse over federal health transfers
}

\author{
Cite as: CMAJ 2017 January 23;189:E127-8. doi: 10.1503/cmaj.109-5376
}

First published at cmaj.ca on Dec. 23, 2016

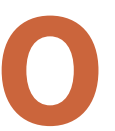
ttawa and the provinces failed to seal a new 10-year deal on federal health funding during a daylong meeting Dec. 19, 2016, despite a lastminute increase to the federal offer.

At the start of the Dec. 19 negotiations in Ottawa, Federal Finance Minister Bill Morneau offered provincial and territorial health ministers an annual increase of $3.5 \%$ to health transfers, which will top $\$ 36$ billion in 2016/17. He also offered \$8 billion over 10 years for home care and mental health, as well as \$544 million over five years for prescription drugs and innovation.

Mid-way through the day, Ottawa added another $\$ 3.5$ billion over 10 years.

Provincial and territorial finance and health ministers refused the deal, although they say they were willing to continue negotiating. "It was the federal government that closed the meeting, ultimately," Ontario Finance Minister Charles Sousa told the National Post.

"They [the federal government] can't continue to make ultimatums, to make threats," Manitoba Health Minister Kelvin Goertzen told the Globe and Mail.

The provincial and territorial ministers say the latest proposal will actually shrink federal health spending over time from $23 \%$ to less than $20 \%$ of total public health care costs. They want a boost to $25 \%$ and believe an annual transfer increase of $5.2 \%$ is required.

In addition, they don't want to take federal money outside the annual escalator, because once it runs out, they could be responsible for maintaining spending.

Since 2004, the Canada Health Transfer $(\mathrm{CHT})$, which is divided among the provinces on a per-capita basis, has grown by $6 \%$ annually, a formula set to expire in March 2017. In 2011, the former
Conservative government announced that starting in 2017/18 the increase would be limited to $3 \%$ or the equivalent of nominal gross domestic product growth (a combination of real GDP and inflation), whichever is higher.

In the absence of a new deal, the health transfer will be limited to that $3 \%$ or nominal economic growth, as well as the longpromised extra \$3 billion for home care.

Canadian Medical Association (CMA) President Dr. Granger Avery said he was disheartened by the lack of progress. "Simply focusing on whether it's a 3.5\% CHT increase or whether it's a 6\% CHT increase, is an insufficient discussion."

Concentrating on the bottom line perpetuates the previous federal government's policy of keeping its involvement in health care at arm's length and simply

A federal proposal to increase health payments to the provinces by $3.5 \%$ annually was refused by the provincial governments. providing money to the provinces and territories to do with as they please. "That was an abrogation of federal responsibility in health care in my view," he said. "The whole idea of how we manage health care in Canada has been based on who screams loudest for the last while. And that really isn't a good way to run a system."

The Health Accord negotiations should focus on collaborative endeavors and setting standards to improve the management of the health system so it works better for Canadians, he added. “This an opportunity we haven't had in two or three decades and here we are spending time arguing about what is in effect the inflation increment rather than talking about what is it that Canadians need."

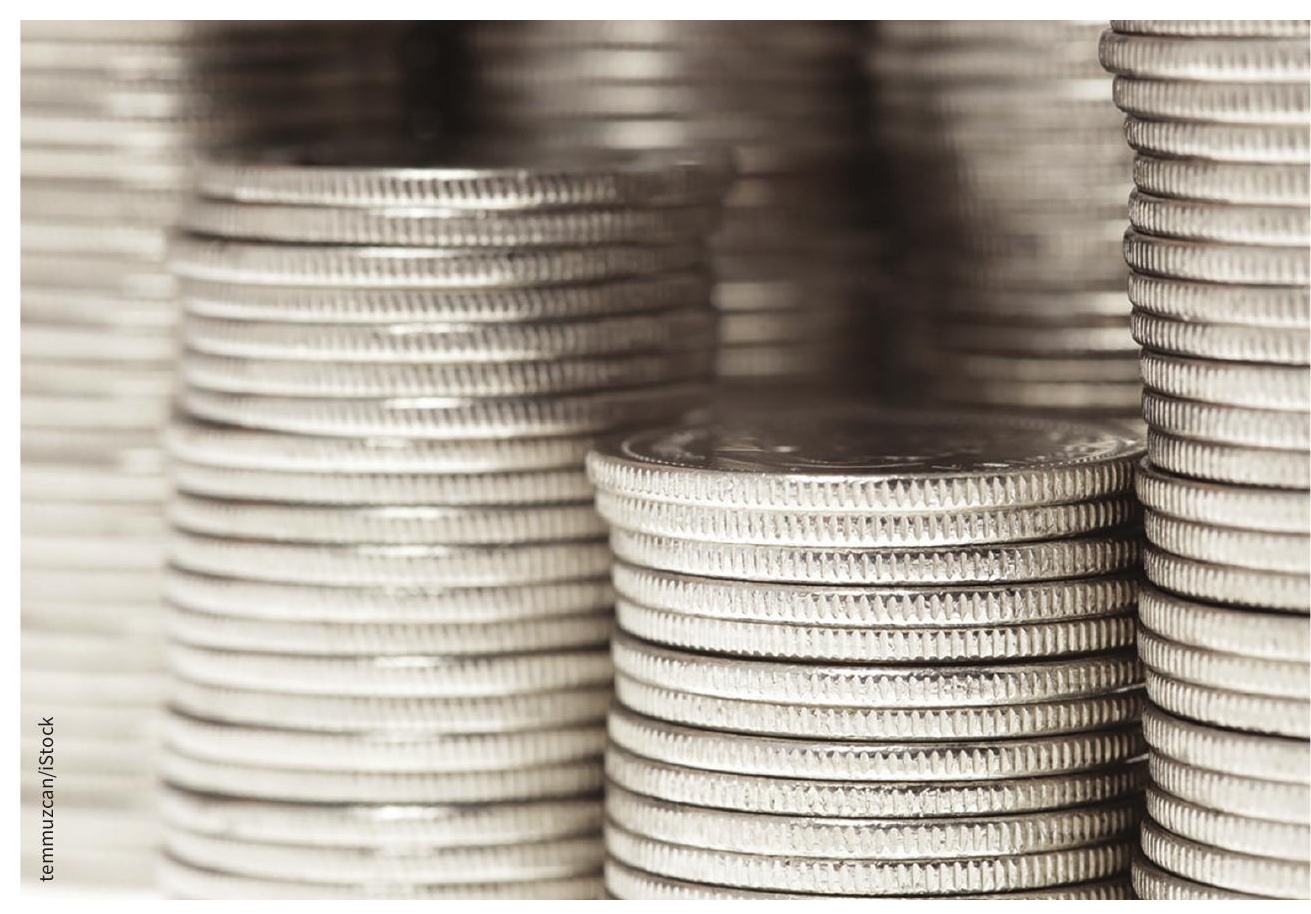


The proposed targeted federal monies could patch certain gaps that need immediate attention, Avery said. "We are so far back in our efficacy that we really do need to get something moving. So frankly, any help to improve care for Canadians, particularly for seniors, is a good idea."

The CMA has advocated particularly for meeting the needs of Canada's aging population, including a demographic top- up of federal funds to support seniors' care in provinces with a disproportionate number of older people.

Federal Health Minister Dr. Jane Philpott, who also attended the Dec. 19 meeting, said earlier this year that the government needs "to do more than simply open the federal wallet." Prior to the Dec. 19 meeting, she told the National Post she was "absolutely delighted" with her govern- ment's "substantial offers on the table." Afterward, she said she was "disappointed that the provinces and territories did not feel they could accept this offer."

In a statement, the Canadian Nurses Association praised the federal offer of new money for home care and remained optimistic that a new agreement could be reached.

Barbara Sibbald, CMAJ 